\title{
LABORATORY COMPACTION STUDY OF FLY ASH MIXED WITH LIME PRECIPITATED ELECTROPLATING WASTE SLUDGE
}

\author{
Malik Shoeb Ahmad ${ }^{1}$ \\ ${ }^{1}$ Associate Professor, Z.H. College of Engineering and Technology, Department of Civil Engineering, Aligarh Muslim \\ University, Aligarh, India
}

\begin{abstract}
This study aims at to utilize two industrial wastes like fly ash and electroplating waste sludge in various geotechnical and highway engineering applications such as filling of embankments, construction of highways, replacement of poor soil etc., by conducting laboratory modified compaction tests on plain fly ash (control specimen) and fly ash mixed with lime precipitated electroplating waste sludge. The lime precipitated waste sludge was mixed with fly ash from 5 to $60 \%$ with an increment of $5 \%$ by weight of fly ash. The combinations of each mixture were investigated in this study in order to evaluate the maximum dry density and optimum moisture content of the mix by modified Proctor compaction tests. The effects of fresh and remoulded samples, waste sludge and compactive effort on compaction properties of fly ash and fly ash-waste sludge mixes were also investigated in the present study. On the basis of modified compaction tests, the effective percentages of waste sludge were found between $30 \%-45 \%$ by weight of fly ash. Therefore, for practical consideration the results of $70 \%-55 \%$ fly ash and 30\%-45\% lime precipitated electroplating waste sludge have been considered in this study.
\end{abstract}

Keywords: Fly ash; Lime Precipitated Electroplating Waste Sludge; Geotechnical and Highway Engineering; Modified Proctor Compaction Test; Compactive Effort

\section{INTRODUCTION}

Rapid industrialization has resulted in environmental pollution of gigantic proportions. The power generation in India through thermal power plants has resulted in the massive production of fly ash, whose disposal has been a challenging task. The present day utilization of fly ash in India is at its infancy, and only an insignificant amount is being put to proper use. Unless efforts of this nature are taken, the menace of fly ash will have disastrous effects on the ecology and environment. Fly ash is reported to cause ailments like allergic bronchitis, silicosis, and asthma. Besides, fly ash contaminates surface water and may also have an effect on underground water due to the presence of heavy metals like lead and arsenic. Besides that one of the major hazardous waste generating industries is the electroplating industry [1]. As the restrictions on landfilling become stronger and wastes were banned from land disposal, stabilization $(\mathrm{S} / \mathrm{S})$ of these wastes could potentially play an important role in making them acceptable for land disposal [2]. This has attracted the attention of many researchers to stabilize the waste sludge containing heavy metals using fly ash and cement [3-9]. On the other hand government has imposed ban on procuring agricultural soil which was earlier used for filling of embankment, plinth and construction of highways subgrade. In order to open up the possibilities, of using alternative materials in place of soil the present study was carried out by using fly ash and fly ash mixed with lime precipitated waste sludge for partial or full replacement of soil. The performance of these mixes depends upon the compaction or densification of the fill. Proper compaction is therefore, critical to the performance of fly ash and fly ash-waste sludge fills. The maximum dry density (MDD) and optimum moisture content (OMC) obtained by Proctor compaction tests becomes the benchmark for determining the quality of compaction. The dry density of fill is of primary importance, since it is the major determinant of strength and compressibility of the fills [10].

The engineering properties of fly ash are varying widely with the fresh and remoulded samples because they depend upon origin, type of coal, combustion process and collection methods. Studies on compaction properties of soils and fly ash reported in the literatures [11-18]. However, the compaction studies on fresh and remoulded samples of fly ash and electroplating waste are very few [19-20]. The present investigation is meant to utilize the fly ash and electroplating waste sludge for highway and geotechnical applications, by conducting modified Proctor tests on plain fly ash and fly ash mixed with lime precipitated electroplating waste. The waste sludge was added to fly ash from 5 to $60 \%$ with an increment of $5 \%$ by weight of fly ash. The literature suggests that the use of fresh/remolded samples for each compaction and preconditioning period can make significant difference in the MDD and OMC values. However, no uniform procedure appears to have been adopted in practice. Therefore, an attempt has been made to investigate the effect of these parameters on MDD and OMC of Harduaganj fly ash and fly ash mixed with waste sludge. 


\section{EXPERIMENTAL PROGRAMME}

\subsection{Materials}

In this study, the materials used are:

(i) Fly ash (FA)

(ii) Electroplating Waste Sludge (S)

(iii) Lime

\subsubsection{Fly Ash}

Fly ash was procured from Harduaganj thermal power plant located at $16 \mathrm{~km}$ from Aligarh City, Uttar Pradesh, India. For the present investigation, dry fly ash from hoppers is collected in polythene bags.

\section{Physical Properties of Fly Ash}

The physical properties fly ash is shown in Table-1. The fly ash used in the present study can be classified as ML (silt of low compressibility).

Table-1: Physical Properties of Fly ash

\begin{tabular}{|l|l|l|}
\hline S. No. & Constituent/Property & Value \\
\hline 1. & Colour & Grey \\
\hline 2. & Percent Finer & $96 \%$ \\
\hline 3. & $\begin{array}{l}\text { Maximum dry density (MDD) - } \\
\text { Modified Test }\end{array}$ & $10.80 \mathrm{kN} / \mathrm{m}^{3}$ \\
\hline 4. & $\begin{array}{l}\text { Optimum moisture content } \\
\text { (OMC) }\end{array}$ & $26.5 \%$ \\
\hline 5. & Specific gravity & $2.10{\mathrm{at} 27^{\circ} \mathrm{C}}^{3} / \mathrm{g}$ \\
\hline 6. & Specific Surface area & $3190 \mathrm{~cm}^{3}$ \\
\hline
\end{tabular}

\section{Chemical Composition of Fly Ash}

The chemical composition of fly ash is shown in Table-2. Figure 1 shows the scanning electron micrographs (SEM) of fly ash. The micrographic observation of fly ash indicates the presence of spherical particles in abundance, sub rounded porous grains, irregular agglomerates, opaque spheres and irregular porous grains of unburned carbon.

Table-2: Chemical Composition of Fly ash

\begin{tabular}{|l|l|}
\hline Constituent/Property & Value (\%) \\
\hline $\mathrm{SiO}_{2}$ & 61.0 \\
\hline $\mathrm{Al}_{2} \mathrm{O}_{3}$ & 20.0 \\
\hline $\mathrm{Fe}_{2} \mathrm{O}_{3}$ & 9.0 \\
\hline $\mathrm{CaO}$ & 2.0 \\
\hline $\mathrm{MgO}$ & 1.4 \\
\hline $\mathrm{SO}_{3}$ & 0.40 \\
\hline
\end{tabular}

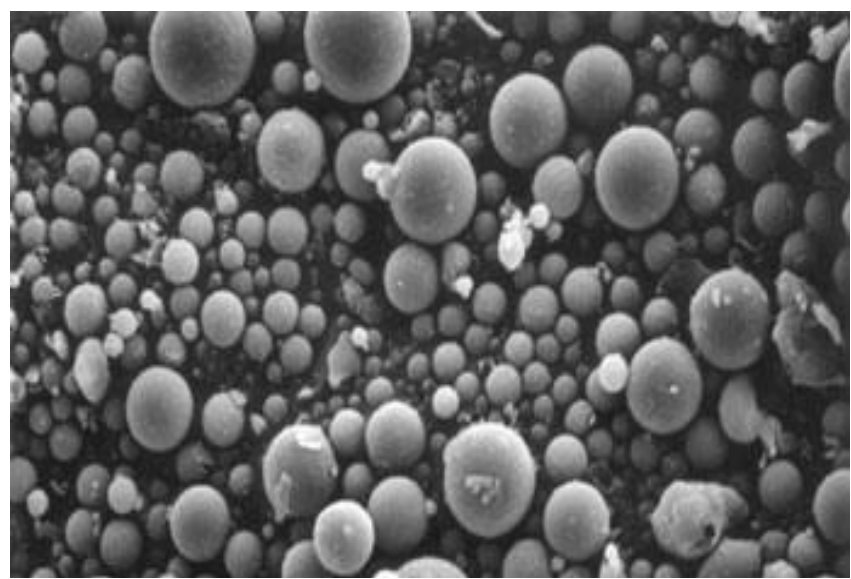

Fig. 1: Scanning Electron Micrograph of Fly ash

\subsubsection{Electroplating Waste Sludge}

The electroplating waste sludge for the present study was collected from local plating industries where $\mathrm{Ni}$ and $\mathrm{Zn}$ plating was done. The plating waste collected for the study comprises of solid refuge which was collected from the bottom of the plating tank. The solid waste includes chemicals, heavy metals and metallic dust. Heavy metal analysis was carried out using GBC-902 atomic absorption spectrophotometer (AAS). The AAS observation shows that the quantity of heavy metals in the electroplating waste sludge was extremely high as shown in Table- 4 . The electroplating sludge was initially mixed with $10 \%$ lime for precipitation of heavy metals. The morphology of the lime precipitated waste sludge was obtained by SEM analysis as shown in Fig. 2.

\section{Physical Properties of Electroplating Waste Sludge}

The chemical composition of electroplating waste sludge is shown in Table-3.

Table-3: Chemical Composition of Electroplating Waste Sludge

\begin{tabular}{|l|l|}
\hline Constituent/Property & Value \\
\hline Total Solids & $119276 \mathrm{mg} / \mathrm{l}$ \\
\hline Total dissolved solids & $5012 \mathrm{mg} / \mathrm{l}$ \\
\hline Total suspended solids & $95643 \mathrm{mg} / 1$ \\
\hline Specific gravity & 1.12 \\
\hline $\mathrm{pH}$ & 2.03 \\
\hline
\end{tabular}

\section{Heavy Metal Composition of Electroplating Waste Sludge}

The heavy metal concentration in electroplating waste sludge is shown in Table- 4 . 
Table-4: Heavy Metal Concentration in Electroplating Waste Sludge

\begin{tabular}{|l|c|}
\hline Metals & $\begin{array}{c}\text { Concentration } \\
\text { (mg/l or ppm) }\end{array}$ \\
\hline Nickel & 813 \\
\hline Chromium & 500 \\
\hline Zinc & 1000 \\
\hline Cadmium & 010 \\
\hline Lead & 003 \\
\hline
\end{tabular}

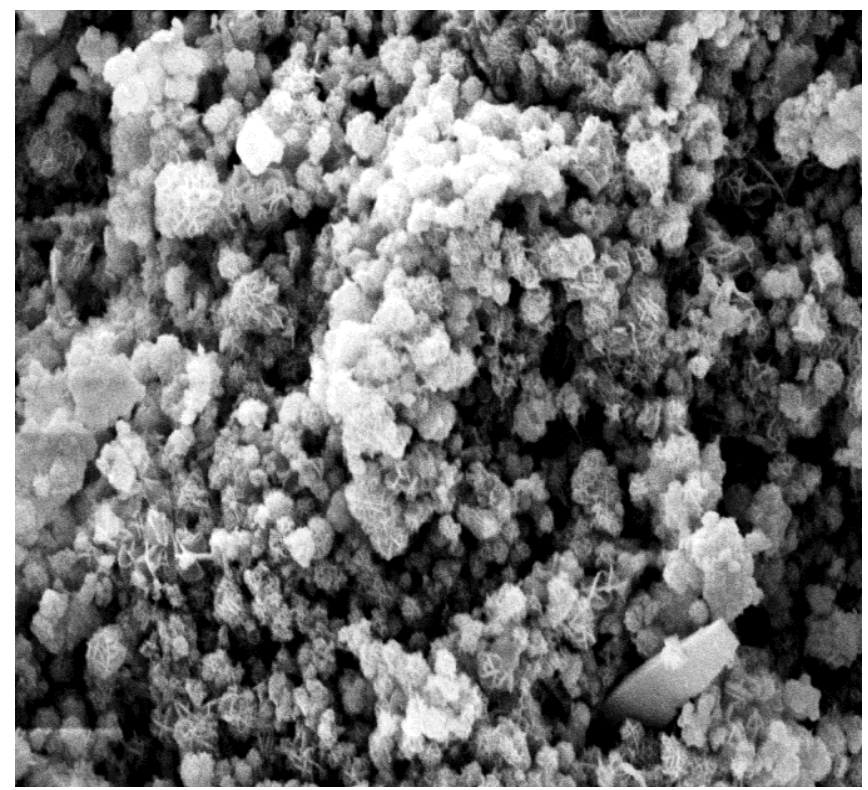

Fig. 2: Scanning Electron Micrograph (SEM) of Lime Precipitated Waste sludge

\section{Lime}

The finely powered white coloured lime was used as precipitator having the chemical composition given in Table-5.

Table-5: Chemical Composition of Lime

\begin{tabular}{|l|l|}
\hline Constituent Properties & Value \\
\hline Assay & $98 \%$ \\
\hline Chloride & $0.01 \%$ \\
\hline Sulphate & $0.2 \%$ \\
\hline Aluminium, iron and insoluble matters & $1.0 \%$ \\
\hline Arsenic & Traces \\
\hline Lead & Traces \\
\hline
\end{tabular}

\subsection{Preparation and Testing of Specimens}

All the specimens tested were prepared by mixing the relevant quantities of fly ash, lime precipitated electroplating waste sludge, and water, according to the mixture proportions. The material was thoroughly mixed to achieve uniform mixing of water. The wet mix was then tested as (i) fresh samples (new samples are used for each test point) (ii) remoulded samples (the same samples were remoulded and reused every time. Modified Proctor compaction tests were carried out using the equipment and procedure as specified in IS: 2720 (Part-8) [21] equivalent to ASTM D 1557 [22]. However, standard Proctor compaction tests were also conducted on some selected specimens for studying the effect of compaction energy on fly ash and mix. The standard Proctor tests were conducted as per the procedure specified in IS: 2720 (Part-7) [23] equivalent to ASTM D 698[24]. Three replicate tests were carried out for each condition. The details of the test conditions are given in Table-6.

Table-6: Details of Test Conditions

\begin{tabular}{|c|c|c|c|c|}
\hline \multirow[t]{2}{*}{ S. No. } & \multirow[t]{2}{*}{ Mix } & \multirow{2}{*}{$\begin{array}{l}\text { Standard } \\
\text { Proctor Tests }\end{array}$} & \multicolumn{2}{|c|}{ Modified Proctor Tests } \\
\hline & & & $\begin{array}{l}\text { Preconditioning } \\
\text { Period }\end{array}$ & $\begin{array}{l}\text { Fresh/ } \\
\text { Remolded }\end{array}$ \\
\hline 1. & Fly ash(FA) & \multirow{6}{*}{ Fresh Samples } & $0,1,16,24 \mathrm{hr}$ & Both \\
\hline 2. & $70 \% \mathrm{FA}+30 \% \mathrm{~S}$ & & $0,1,16,24 \mathrm{hr}$ & Both \\
\hline 3. & $65 \% \mathrm{FA}+35 \% \mathrm{~S}$ & & $0,1,16,24 \mathrm{hr}$ & Both \\
\hline 4. & $60 \% \mathrm{FA}+40 \% \mathrm{~S}$ & & $0,1,16,24 \mathrm{hr}$ & Both \\
\hline 5. & $55 \% \mathrm{FA}+45 \% \mathrm{~S}$ & & $0,1,16,24 \mathrm{hr}$ & Both \\
\hline 6. & $50 \% \mathrm{FA}+50 \% \mathrm{~S}$ & & $0,1,16,24 \mathrm{hr}$ & Both \\
\hline
\end{tabular}




\section{RESULTS AND DISCUSSION}

The result of Proctor tests conducted on fly ash and fly ashwaste sludge blends are presented and discussed to bring out the effect of various factors on compaction parameters.

\subsection{Influence of Compactive Effort}

Standard and modified Proctor compaction tests were conducted on fly ash and fly ash-waste sludge blend to study the effect of compaction energy. Typical compaction curves of plain fly ash and most effective mix $55 \% \mathrm{FA}+45 \% \mathrm{~S}$ are shown in Figs. $3 \& 4$. A compilation of few reported data pertaining to soils and fly ash on the effect of compaction energy on MDD and OMC values are also presented in Table-7. It has been observed that the increase in compaction effort has resulted in $16.12 \%$ increase in MDD and 4\% decrease in OMC values of fly ash with respect to standard Proctor test. While out of various combination of fly ash-waste sludge blend the most significant mix was found to be $55 \% \mathrm{FA}+45 \% \mathrm{~S}$. The effect of compaction energy can also be seen in case of this mix. The increase in MDD value w.r.t. standard Proctor tests is about $14.23 \%$ whereas, the decrement in OMC value is observed as $6.5 \%$. The data presented in Table-7 show that the results of the present investigations on Harduaganj fly ash and fly ash-waste sludge mixes are in conformity with those observed for soils and fly ashes obtained from other sources.

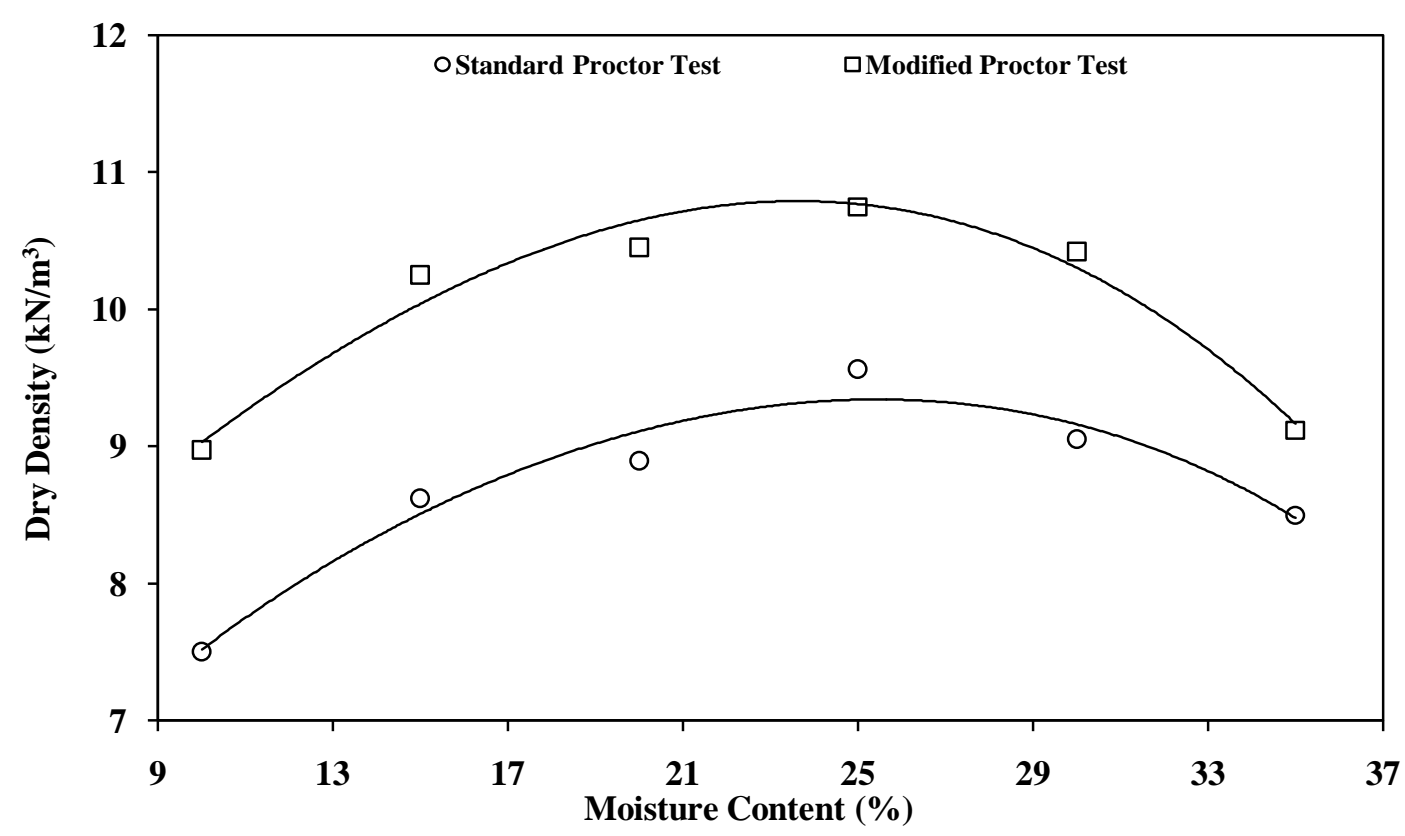

Fig. 3: Effect of Compaction Energy on Compaction Properties of Fly ash (Fresh)

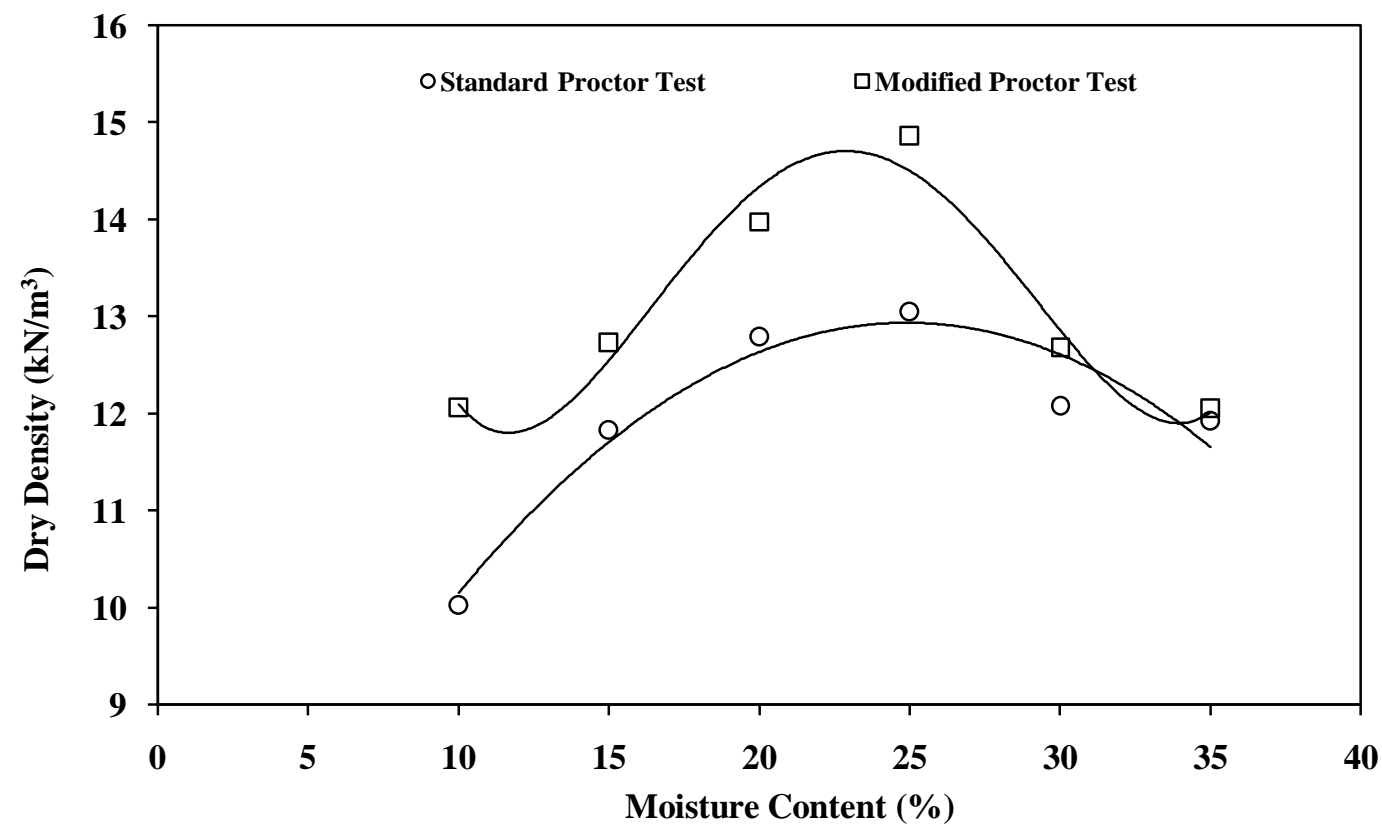

Fig. 4: Effect of Compaction Energy on Compaction Properties of 55\%FA+45\%S (Fresh) 
Table-7: The Influence of Compactive Effort on the MDD and OMC of Soil, Fly ash and Fly ash-Waste Sludge

\begin{tabular}{|c|c|c|c|c|c|c|}
\hline \multirow[t]{2}{*}{ Type of Material } & \multicolumn{3}{|c|}{$\operatorname{MDD}\left(\mathbf{k N} / \mathbf{m}^{3}\right)$} & \multicolumn{3}{|c|}{ OMC (\%) } \\
\hline & $\begin{array}{l}\text { Standard } \\
\text { Proctor }\end{array}$ & $\begin{array}{l}\text { Modified } \\
\text { Proctor }\end{array}$ & $\begin{array}{l}\text { \% Variation } \\
\text { w.r.t. } \\
\text { Standard }\end{array}$ & $\begin{array}{l}\text { Standard } \\
\text { Proctor }\end{array}$ & $\begin{array}{l}\text { Modified } \\
\text { Proctor }\end{array}$ & $\begin{array}{l}\text { \% Variation } \\
\text { w.r.t. } \\
\text { Standard }\end{array}$ \\
\hline \multicolumn{7}{|l|}{ Toth et al. [25] } \\
\hline Heavy Clay & 15.84 & 19.10 & 20.58 & 28.00 & 18.00 & -35.71 \\
\hline Silty Clay & 16.98 & 19.76 & 16.37 & 21.00 & 12.00 & -42.85 \\
\hline Sandy Clay & 18.78 & 20.90 & 11.29 & 14.00 & 11.00 & -21.43 \\
\hline Sand & 19.76 & 21.22 & 07.39 & 11.00 & 09.00 & -18.18 \\
\hline Gravel-sand-clay mix & 21.07 & 22.37 & 06.17 & 09.00 & 08.00 & -11.11 \\
\hline Fly ash (Lambton G.S) & 11.69 & 12.64 & 08.13 & 36.00 & 26.00 & -27.77 \\
\hline $\begin{array}{l}\text { Bottom Ash (Lambton } \\
\text { G.S) }\end{array}$ & 10.24 & 16.31 & 59.28 & 28.00 & 17.00 & -39.29 \\
\hline $\begin{array}{l}\text { Bottom Ash } \\
\text { (Lakeview G.S) }\end{array}$ & 13.00 & 16.32 & 25.54 & 29.00 & 18.00 & -37.23 \\
\hline $\begin{array}{l}\text { Martin et al. [26] } \\
\text { Bottom Ash }\end{array}$ & 10.50 & 11.60 & 8.57 & 28.00 & 25.00 & -11.40 \\
\hline \multicolumn{7}{|l|}{ Santayana and Mazo [27] } \\
\hline Fly ash (Los Barrios CCS) & 10.90 & 11.80 & 8.26 & 38.00 & 32.00 & -15.78 \\
\hline Fly ash (Los Barrios CCE) & 12.80 & 13.70 & 7.03 & 27.00 & 22.00 & -18.52 \\
\hline Fly ash (Los Barrios CM) & 12.50 & 13.60 & 8.80 & 27.50 & 22.50 & -18.18 \\
\hline Fly ash (Puertollano) & 12.50 & 13.10 & 4.80 & 22.00 & 19.30 & -12.27 \\
\hline Fly ash (Lada CCF) & 12.00 & 12.50 & 4.17 & 27.70 & 24.10 & -13.00 \\
\hline Fly ash (Lada CCF) & 15.00 & 15.30 & 2.10 & 17.50 & 17.40 & -00.60 \\
\hline \multicolumn{7}{|c|}{ Ramasamy and Pusadkar [20] } \\
\hline Dadri Fly ash & 12.96 & 13.85 & 06.86 & 19.63 & 18.47 & -05.91 \\
\hline Dadri Bottom ash & 08.84 & 10.31 & 16.63 & 47.17 & 35.07 & -25.65 \\
\hline \multicolumn{7}{|c|}{ Present Study-Harduaganj Fly ash (2014) } \\
\hline Fly ash(FA) & 09.30 & 10.80 & 16.12 & 27.50 & 26.50 & -04.00 \\
\hline $70 \% \mathrm{FA}+30 \% \mathrm{~S}$ & 11.50 & 12.50 & 09.00 & 27.00 & 25.00 & -07.40 \\
\hline $65 \% \mathrm{FA}+35 \% \mathrm{~S}$ & 12.06 & 12.90 & 07.00 & 26.50 & 24.00 & -9.40 \\
\hline $60 \% \mathrm{FA}+40 \% \mathrm{~S}$ & 12.40 & 13.50 & 08.80 & 23.00 & 24.20 & -05.20 \\
\hline $55 \% \mathrm{FA}+45 \% \mathrm{~S}$ & 13.00 & 14.85 & 14.23 & 24.50 & 23.00 & -06.50 \\
\hline $50 \% \mathrm{FA}+50 \% \mathrm{~S}$ & 12.65 & 13.20 & 04.30 & 25.00 & 24.00 & -04.00 \\
\hline
\end{tabular}

\subsection{Effect of Waste Sludge}

The effect of waste sludge on compaction of fly ash is shown in Fig. 5. It has been envisaged from the Fig. 5 that the values of MDD are significantly increasing with addition of waste sludge to the fly ash. It may also be observed that the most significant waste sludge percentage is between $35 \%$ to $45 \%$ by weight of fly ash. The percent increase in MDD values w.r.t. plain fly ash is observed as $37.5 \%$ for $55 \% \mathrm{FA}+45 \% \mathrm{~S}$ mix. However, on increasing the waste sludge beyond $45 \%$, the maximum dry density of fly ashwaste sludge blend decreases and optimum moisture content increases. This may be attributed to the presence of excess amount lime in the mix, which reacts quickly with the fly ash and brings changes in base exchange aggregation and flocculation, resulting in increased void ratio of the mix leading to a decreased density of the mix. On the other hand it has also been observed that the mix containing high percentage of fly ash may possess low value of MDD and high value of OMC. This might be due to the dominance of fly ash which is having a relatively low specific gravity results in reduced MDD value. The increase in optimum moisture content can be attributed towards the increasing amount of fines which require more water content due to increased surface areas. 


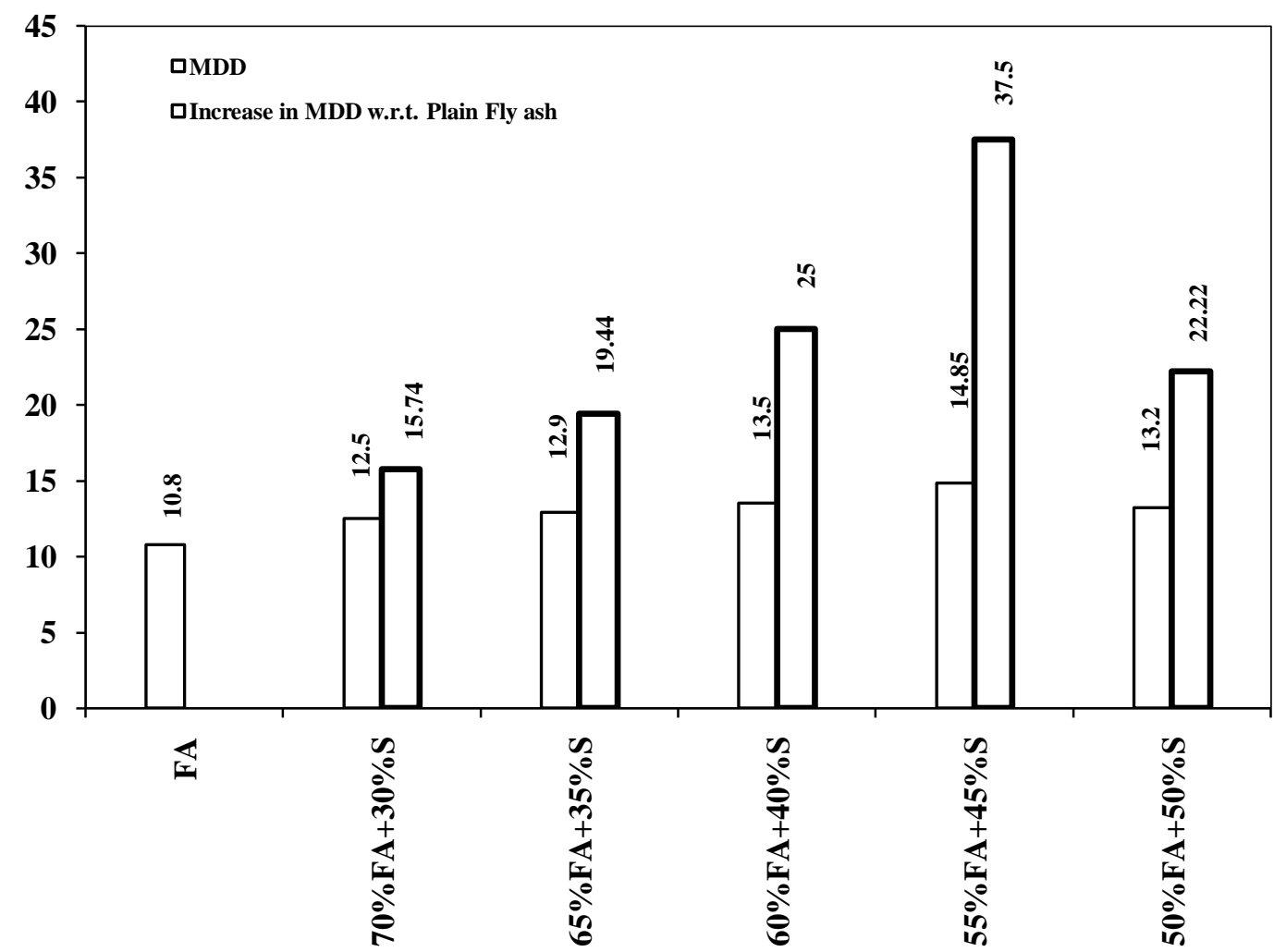

Fig. 5: Effect of Waste Sludge on MDD of Fly ash for Fresh Sample (Modified Proctor Test)

\subsection{Influence of Fresh and Remoulded Samples}

Some typical results of modified Proctor compaction tests obtained for fly ash and fly ash-waste sludge blends are presented in Table- 8 and Figs. 6 to 13. The results show that the use of remoulded sample increases the value of MDD and decreases the value of OMC of fly ash and fly ashwaste sludge blend. This may be attributed to crushing of ash grains due to repeated compaction of the sample as well as enhanced lubrication mechanism due to uniform distribution of moisture in the fly ash-waste sludge blend. It may also be observed that the increase in the MDD of remoulded samples of fly ash-waste sludge blend is more significant than fly ash. The percent increase in MDD values of remoulded samples with respect to fresh samples are $9.30 \%$ for fly ash, $10.4 \%$ for $70 \% \mathrm{FA}+30 \% \mathrm{~S}$ and $19 \%$, $17 \%, 8.5 \%$ \& $5 \%$ for $65 \% \mathrm{FA}+35 \% \mathrm{~S}, 60 \% \mathrm{FA}+40 \% \mathrm{~S}$, $55 \% \mathrm{FA}+45 \% \mathrm{~S}$ and $50 \% \mathrm{FA}+50 \% \mathrm{~S}$ mixes respectively. This indicates that the delay in mixing and laying of the mix at site may not cause decrease in the MDD values. However, the use of fresh samples would simulate the field condition more closely, the procedure of using fresh samples may be adopted for carrying out compaction tests on fly ash, fly ash-waste sludge blend.

Table-8: Effect of Fresh/Remoulded Samples on MDD and OMC (Modified Test)

\begin{tabular}{|c|c|c|c|c|}
\hline \multirow[t]{2}{*}{ Proctor Test } & \multicolumn{2}{|c|}{ Fresh Sample } & \multicolumn{2}{|c|}{ Remoulded Sample } \\
\hline & $\operatorname{MDD}\left(k N / m^{3}\right)$ & $\operatorname{OMC~}(\%)$ & $\operatorname{MDD}\left(k N / m^{3}\right)$ & OMC (\%) \\
\hline Fly ash (FA) & 10.80 & 26.5 & 11.80 & 23.90 \\
\hline $70 \% \mathrm{FA}+30 \% \mathrm{~S}$ & 12.50 & 25.0 & 13.80 & 21.00 \\
\hline $65 \% \mathrm{FA}+35 \% \mathrm{~S}$ & 12.90 & 24.0 & 15.30 & 23.60 \\
\hline $60 \% \mathrm{FA}+40 \% \mathrm{~S}$ & 13.50 & 24.2 & 15.80 & 24.00 \\
\hline $55 \% \mathrm{FA}+45 \% \mathrm{~S}$ & 14.85 & 23.0 & 16.10 & 23.00 \\
\hline $50 \% \mathrm{FA}+50 \% \mathrm{~S}$ & 13.20 & 24.0 & 13.80 & 22.00 \\
\hline
\end{tabular}




\subsection{Effect of Preconditioning Period}

The results of modified Proctor compaction tests on fly ash and fly ash-waste sludge samples with preconditioning period as $0 \mathrm{hr}, 1 \mathrm{hr}, 16 \mathrm{hr}$ and $24 \mathrm{hr}$, are shown in Table-9 and Figs. 6 to 13. It has been observed from tests results that the values of MDD are increasing $(0 \mathrm{hr}=10.80$ and 16 $\mathrm{hr}=11.20 \mathrm{kN} / \mathrm{m}^{3}$ ) whereas, the OMC values are also increasing slightly with increase in preconditioning period from $0-16$ hours $(0 \mathrm{hr}=26.5$ and $16 \mathrm{hr}=27.5 \%)$ for all the combinations of fly ash-waste sludge blend in general and fly ash in particular. However, the percentage increase in the value of MDD of fly ash-waste sludge blend for $16 \mathrm{hr}$ of preconditioning period with respect to $0 \mathrm{hr}$ are $5.6 \%$ for $70 \% \mathrm{FA}+30 \% \mathrm{~S}$ and $7.7 \%, 3.8 \%, 9.0 \% \& 0.0 \%$ for $65 \% \mathrm{FA}+35 \% \mathrm{~S}, \quad 60 \% \mathrm{FA}+40 \% \mathrm{~S}, \quad 55 \% \mathrm{FA}+45 \% \mathrm{~S}$ and $50 \% \mathrm{FA}+40 \% \mathrm{~S}$ mixes respectively. The most significant mix is found $55 \% \mathrm{FA}+45 \% \mathrm{~S}$. Whereas, the MDD value of mix $50 \% \mathrm{FA}+50 \% \mathrm{~S}$ has not been increased significantly with increase in preconditioning period. The finding indicates that due to carbonation reaction, the mix $50 \% \mathrm{FA}+50 \% \mathrm{~S}$ becomes porous results in decrease in MDD values. Therefore, this finding reveals that the delay caused due to mixing and laying of the mix at site at least upto 16 hours may not cause decrease in the density of the mix blend.

Table-9: Effect of Preconditioning Period on MDD and OMC of Fly ash and Fly ash-Waste Sludge Mix

\begin{tabular}{|c|c|c|c|c|c|c|c|c|c|c|c|c|c|}
\hline \multirow{2}{*}{$\begin{array}{l}\text { S. } \\
\text { No. }\end{array}$} & \multirow{2}{*}{$\begin{array}{c}\text { Preconditioning } \\
\text { period }\end{array}$} & \multicolumn{2}{|c|}{ Fly ash (FA) } & \multicolumn{2}{|c|}{$70 \% \mathrm{FA}+30 \% \mathrm{~S}$} & \multicolumn{2}{|c|}{$65 \% \mathrm{FA}+35 \% \mathrm{~S}$} & \multicolumn{2}{|c|}{$60 \% \mathrm{FA}+40 \% \mathrm{~S}$} & \multicolumn{2}{|c|}{$55 \% \mathrm{FA}+45 \% \mathrm{~S}$} & \multicolumn{2}{|c|}{$50 \% \mathrm{FA}+50 \% \mathrm{~S}$} \\
\hline & & $\underset{\left(\mathbf{k N} / \mathbf{m}^{3}\right)}{\text { MDD }}$ & $\begin{array}{c}\text { OMC } \\
(\%)\end{array}$ & $\underset{\left(\mathbf{k N} / \mathbf{m}^{3}\right)}{\mathrm{MDD}}$ & $\begin{array}{c}\text { OMC } \\
(\%)\end{array}$ & $\underset{\left(\mathbf{k N} / \mathbf{m}^{3}\right)}{\operatorname{MDD}}$ & $\begin{array}{c}\text { OMC } \\
(\%)\end{array}$ & $\underset{\left(\mathbf{k N} / \mathbf{m}^{3}\right)}{\operatorname{MDD}}$ & $\begin{array}{c}\text { OMC } \\
(\%)\end{array}$ & $\underset{\left(\mathbf{k N} / \mathbf{m}^{3}\right)}{\text { MDD }}$ & $\begin{array}{c}\text { OMC } \\
(\%)\end{array}$ & $\underset{\left(\mathbf{k N} / \mathbf{m}^{3}\right)}{\operatorname{MDD}}$ & $\underset{(\%)}{\text { OMC }}$ \\
\hline \multicolumn{14}{|c|}{ Modified Proctor Test } \\
\hline 1. & $0 \mathrm{hr}$ & 10.80 & 26.50 & 12.50 & 25.00 & 12.90 & 24.00 & 13.50 & 24.20 & 14.85 & 23.00 & 13.20 & 24.00 \\
\hline 2. & $1 \mathrm{hr}$ & 12.25 & 27.10 & 12.78 & 25.30 & 13.20 & 25.80 & 13.40 & 25.20 & 14.20 & 25.00 & 13.50 & 24.20 \\
\hline 3. & $16 \mathrm{hr}$ & 11.20 & 27.50 & 13.20 & 25.00 & 13.90 & 25.20 & 14.02 & 25.42 & 16.20 & 25.60 & 13.20 & 24.50 \\
\hline 4. & $24 \mathrm{hr}$ & 10.80 & 27.00 & 11.25 & 24.90 & 13.20 & 29.10 & 13.50 & 25.50 & 13.58 & 23.10 & 12.02 & 25.90 \\
\hline
\end{tabular}

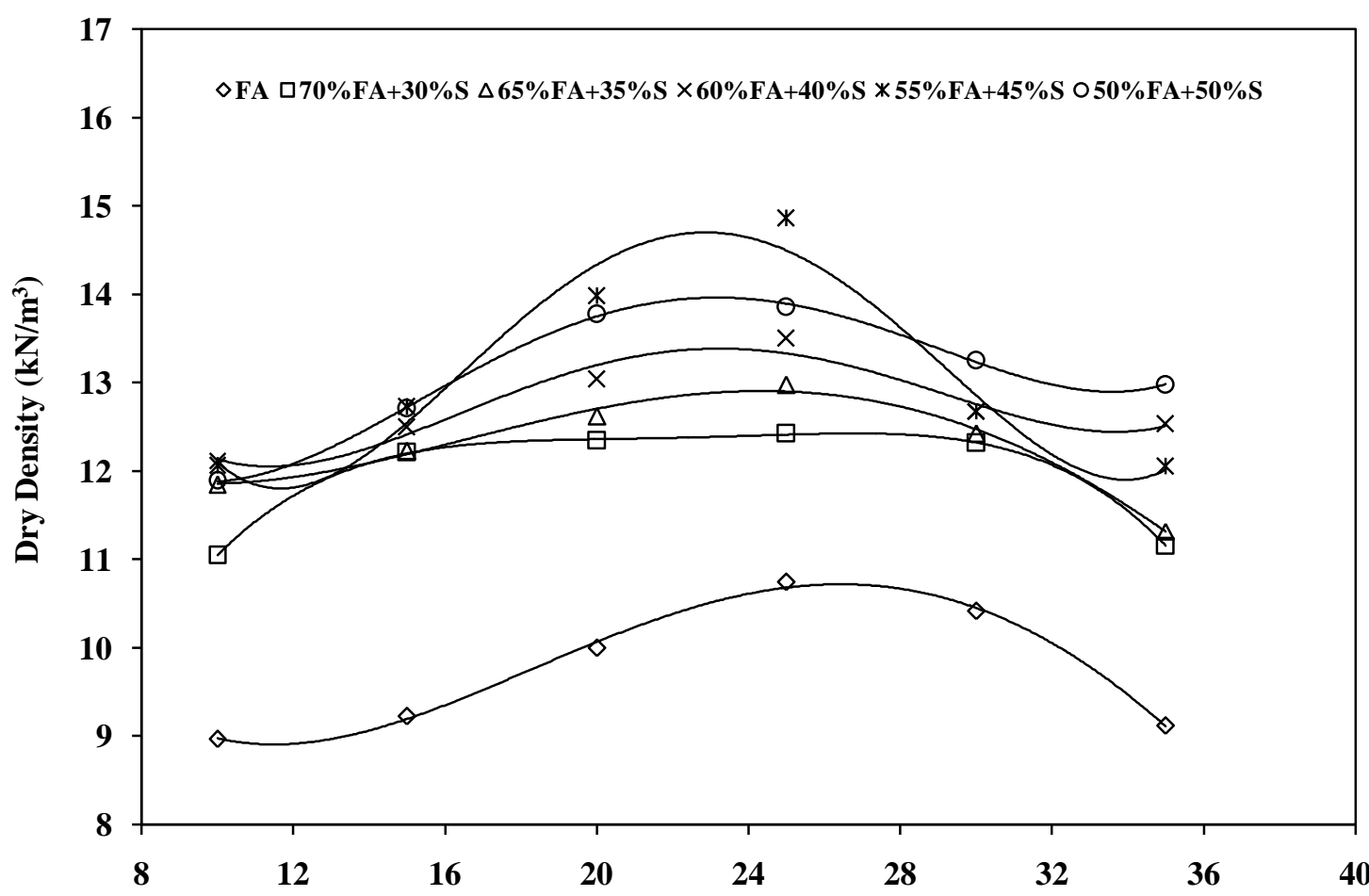

Moisture Content (\%)

Fig. 6: Compaction of Fresh Fly ash-Waste Sludge Mix (Modified Proctor Test-Preconditioning Period= 0 hr) 


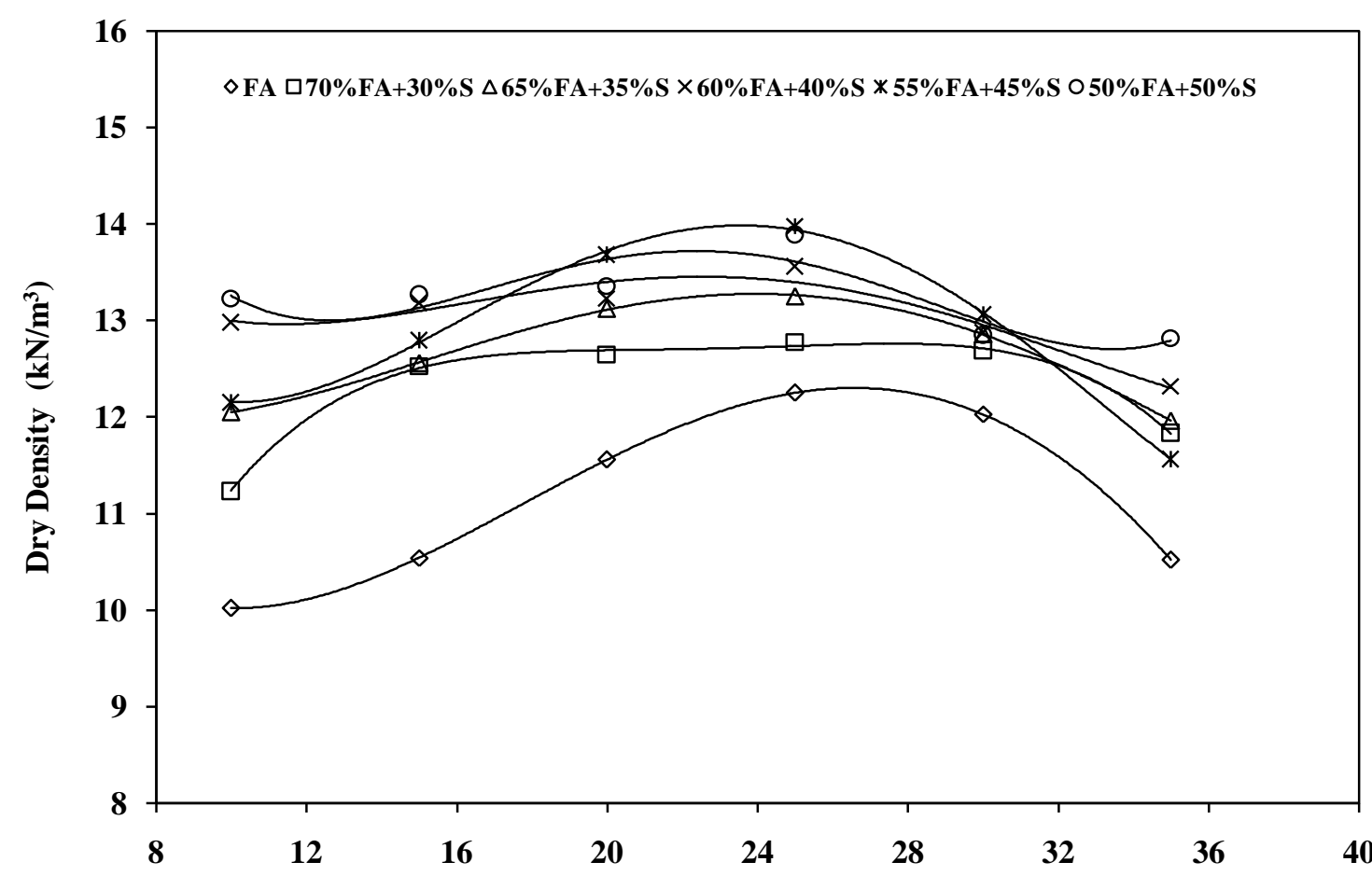

Moisture Content (\%)

Fig. 7: Compaction of Fresh Fly ash-Waste Sludge Mix (Modified Proctor Test-Preconditioning Period $=1 \mathrm{hr}$ )

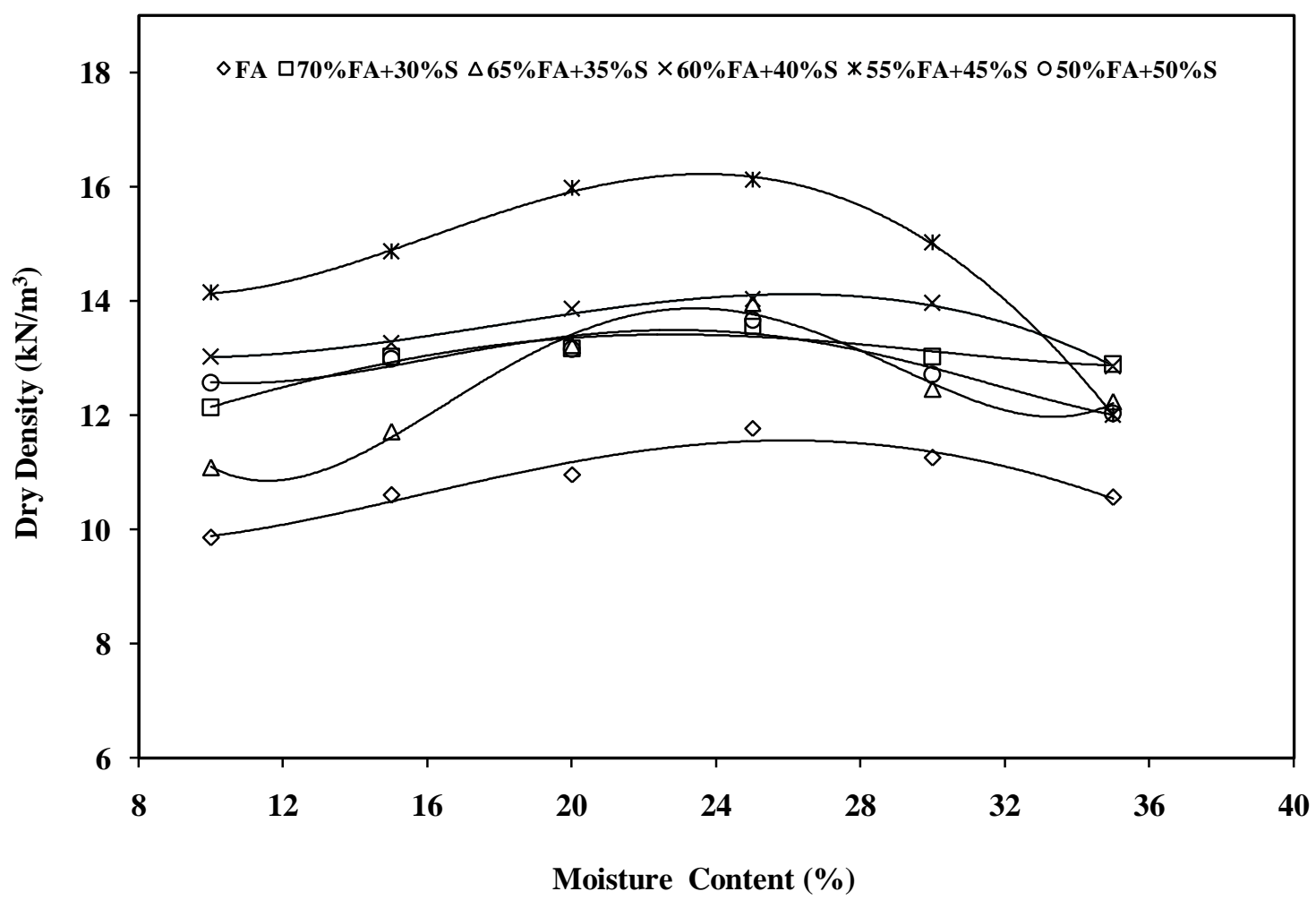

Fig. 8: Compaction of Fresh Fly ash-Waste Sludge Mix (Modified Proctor Test-Preconditioning Period $=16$ hr) 


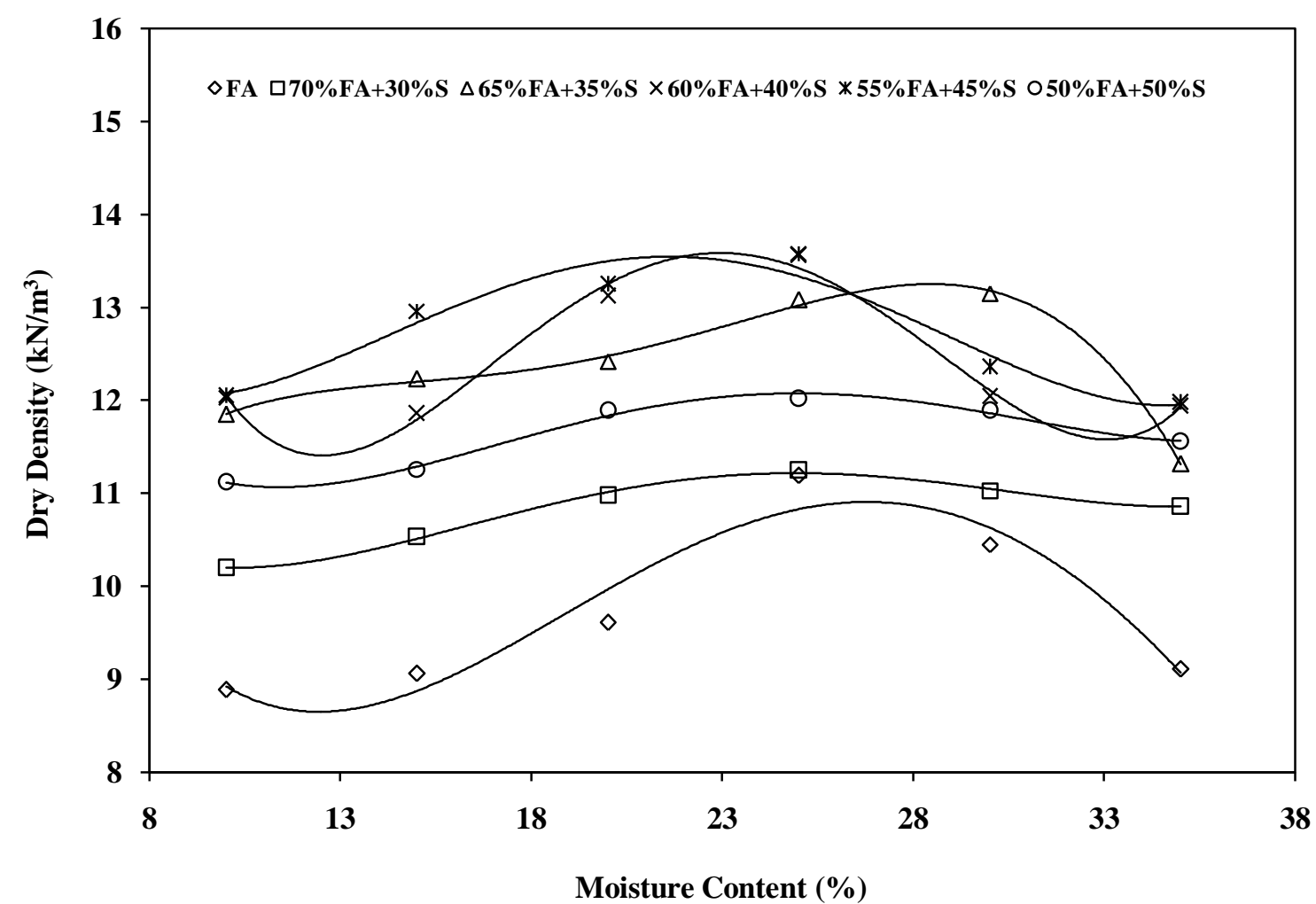

Fig. 9: Compaction of Fresh Fly ash-Waste Sludge Mix (Modified Proctor Test-Preconditioning Period $=24 \mathrm{hr}$ )

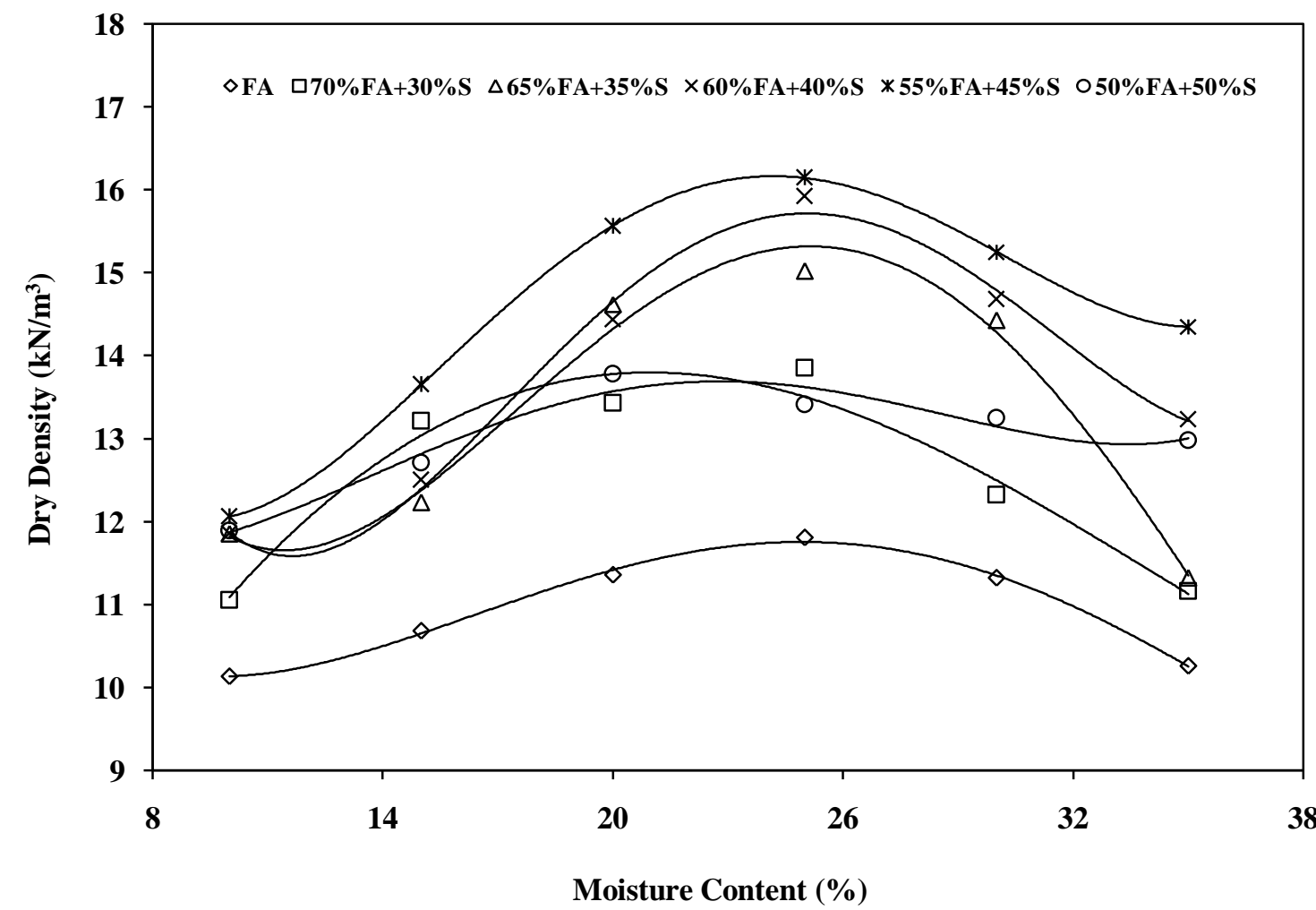

Fig. 10: Compaction of Remoulded Fly ash-Waste Sludge Mix (Modified Proctor Test-Preconditioning Period $=0 \mathrm{hr}$ ) 


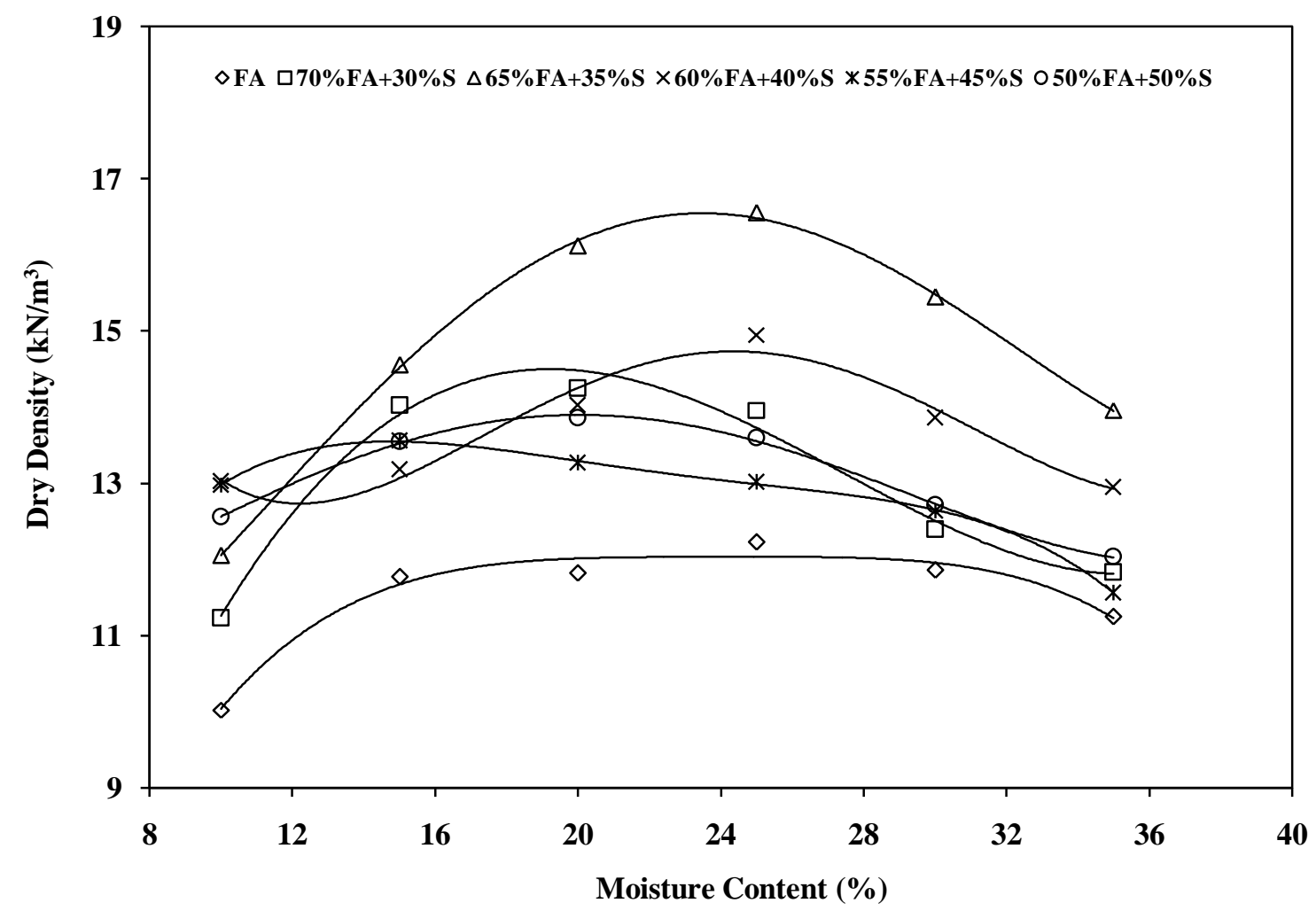

Fig. 11: Compaction of Remoulded Fly ash-Waste Sludge Mix (Modified Proctor Test-Preconditioning Period $=1 \mathrm{hr}$ )

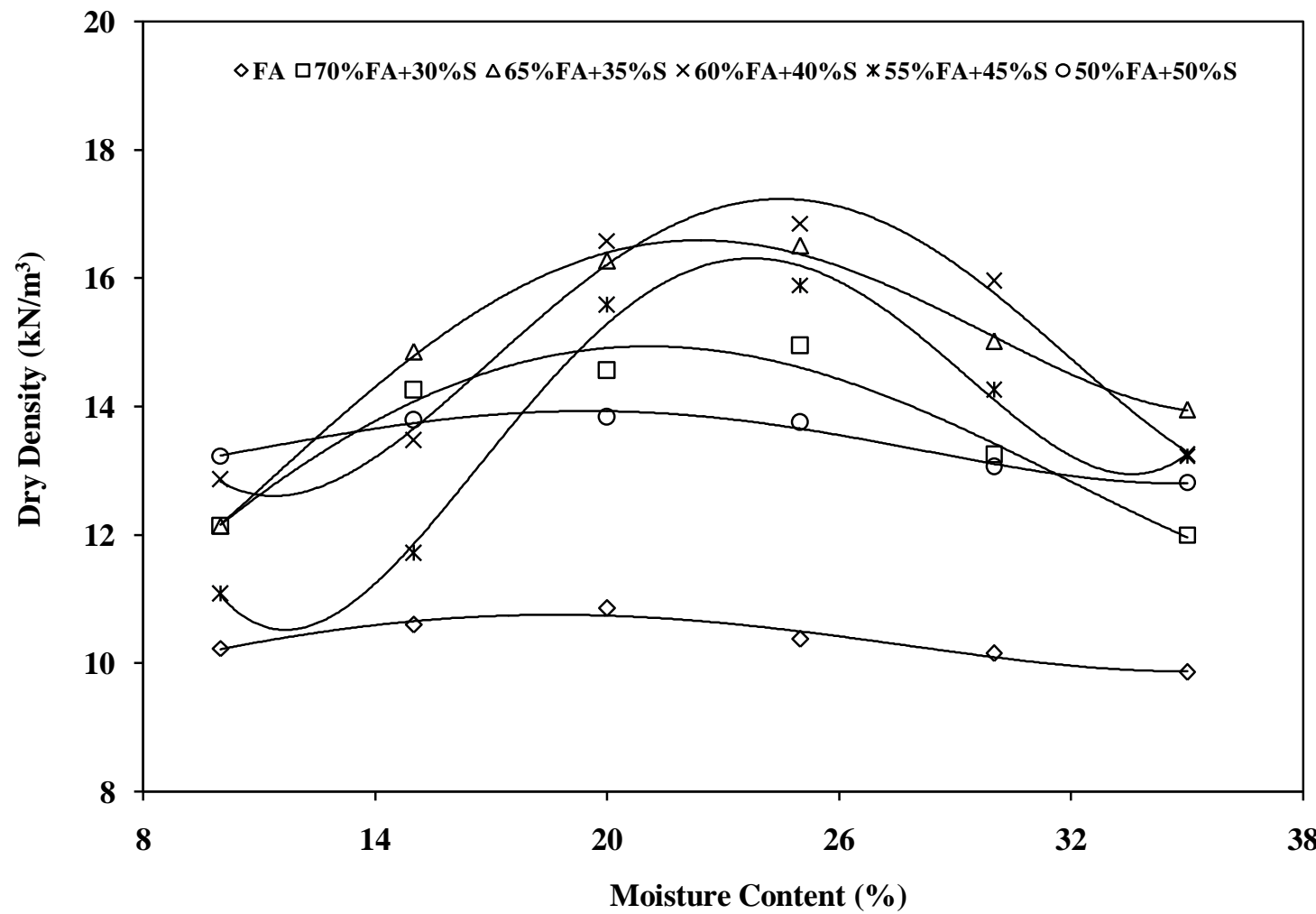

Fig. 12: Compaction of Remoulded Fly ash-Waste Sludge Mix (Modified Proctor Test-Preconditioning Period = $16 \mathrm{hr}$ ) 


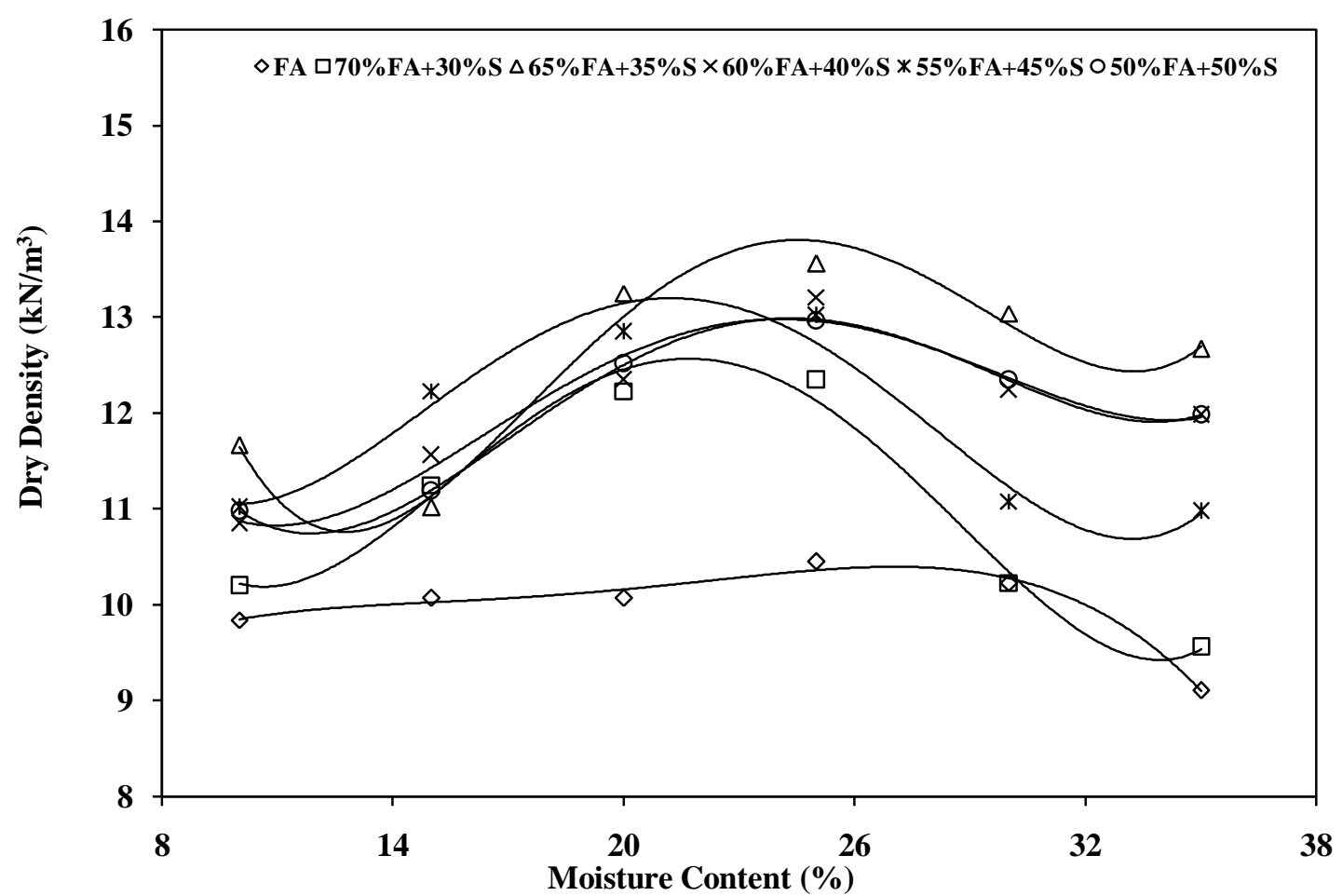

Fig. 13: Compaction of Remoulded Fly ash-Waste Sludge Mix (Modified Proctor Test-Preconditioning Period $=24$ hr)

\section{CONCLUSIONS}

On the basis of the results of the experimental investigation and the discussions made in the earlier sections, the following conclusions are drawn:

It has been observed that the increase in compaction effort has resulted in $16.12 \%$ increase in MDD and $4 \%$ decrease in OMC of fly ash by modified Proctor test with respect to standard Proctor test.

Out of various combination of fly ash-waste sludge blend the most significant mix was found to be $55 \% \mathrm{FA}+45 \% \mathrm{~S}$. The MDD value of this mix has been observed as 14.85 and $16.20 \mathrm{kN} / \mathrm{m}^{3}$ at 0 and 16 hour preconditioning periods respectively.

The percent increase in MDD values of the mix $55 \% \mathrm{FA}+45 \% \mathrm{~S}$ has been observed as $37.5 \%$ as compared to plain fly ash.

The use of remoulded sample increases the value of MDD and decreases the value of OMC for fly ash and fly ashwaste sludge blend.

Preconditioning period is found to have influence on the MDD values of fly ash and fly ash-waste sludge. Therefore, a period equivalent to the expected time interval between wetting and compaction in the field may be adopted as preconditioning period for all types of fly ash and fly ashwaste sludge mix in the laboratory.

In order to achieve good quality structural fills, modified Proctor MDD may be adopted as a benchmark value.

The mix blend containing fly ash between 55\%-65\% and waste sludge blend between $35 \%-45 \%$ gives good results and may be adopted for geotechnical applications.

\section{REFERENCES}

[1] Roy, T. K., Chattopadhyay, B. C. and Roy, S. K. (2009). "Effect of lime on the properties of subgrade of roads with addition of rice husk ash." Indian Geotechnical Conference, India, 175-177.

[2] Weng, C. H., and Huang, C. P. (1994). "Treatment of metal industrial waste water by fly ash and cement fixation." Journal of Environmental Engineering, 120 (6), 1470-1487.

[3] Parsa, J., Stuart, H., McGee, M., and Steiner, R. (1996). "Stabilization/Solidification of hazardous wastes using fly ash." Journal of Environmental Engineering, 122(10), 935-939.

[4] Sophia, C. A. and Swaminathan, K. (2005). "Assessment of the mechanical stability and chemical leachability of immobilized electroplating waste." Chemosphere, 58, 75-82.

[5] T"urkel, S. (2006). "Long-term compressive strength and some other properties of controlled low strength materials made with pozzolanic cement and Class C fly ash." Journal of Hazardous Materials, B 137, 261-266.

[6] Ahmad, M. S. and Shah, S. S. (2010). "Load bearing strength of fly ash modified with cement and waste sludge." International Journal of Civil Engineering (IJCE), 8(4), 315-326.

[7] Yahya Hamzeh, A Kamran Pourhooshyar Ziabari A, Javad Torkaman B, Alireza Ashori C, Mohammad Jafari (2013). "Study on the effects of white rice husk ash and fibrous materials additions on some properties of fiber-cement composites." Journal of Environmental Management, 117, 263-267. 
[8] Saeid. Amiralian, Amin. Chegenizadeh, and Hamid. Nikraz (2012). "Laboratory Investigation on the Compaction Properties of Lime and Fly Ash Composite." International Conference on Civil and Architectural applications (ICCAA'2012) December 18-19, 2012 Phuket (Thailand).

[9] Shah, S. S., and Ahmad, M. S. (2008). "Stabilization of heavy metal containing waste using fly ash and cement." Indian Geotechnical Journal, 38(1), 89100.

[10] Clark, B. G., and Coombs, R. (1996). "Specifying and using pulverized fuel ash as an engineered fill." Waste Management, 16(1-3), 101-108.

[11] Singh, B and Goswami, R. (2012). "Compaction characteristics of lateritic soil mixed with fly ash and lime." International Journal of Geotechnical Engineering., 6:4, 437-444.

[12] Kampala, A, Horpibulsuk, S, Chinkullijniwat, A. and Shen, S. (2013). "Engineering properties of recycled calcium carbide residue stabilized clay as fill and pavement materials."Construction and Building Materials (ASCE) 46, 203-210.

[13] Mohamedzein, Y and Al-Aghbari, M. (2012). "The Use of Municipal Solid Waste Incinerator Ash to Stabilize Dune Sands." Geotechnical and Geological Engineering (ASCE). 30:6, 1335-1344.

[14] Behera, B and Mishra, M. (2012). "Strength behaviour of surface coal mine overburden-fly ash mixes stabilised with quick lime."International Journal of Mining, Reclamation and Environment(ASCE). 26:1, 38-54.

[15] Nilo Cesar Consoli, Amanda Dalla Rosa, and Rodrigo Beck Saldanha (2011). "Variables governing strength of compacted soil-fly ash-lime mixtures." Journal of Materials in Civil Engineering (ASCE). 23:4, 432-440.

[16] Bera, A. K., Ghosh, A. and Ghosh, A. (2007). "Compaction characteristics of pond ash." Journal of Materials in Civil Engineering, 19(4), 349-357.

[17] Kaniraj, S. R. and Havanagi, V. G. (2001). "Correlation analysis of laboratory compaction of fly ashes." Practice Periodical of Hazardous, Toxic, and Radioactive Waste Management, 5(1), 25-32.

[18] Ghosh, A., and Subbarao, C. (2007). "Strength characteristics of Class F fly ash modified with lime and gypsum." Journal of Geotechnical and Geoenvironmental Engineering, 133(7), 757-766.

[19] Leonards, G. A. and Bailey, B. (1982). "Pulverized coal ash as structural fill." Journal of Soil Mechanics and Foundation Division, 108, 517-531.

[20] Ramasamy, G., and Pusadkar, S. S. (2004). "Behaviour of compacted coal ash in structural fills." First CUSAT National Conference on Recent Advances in Civil Engineering, 226-233.

[21] IS: 2720 Part-8 (1983). "Methods of test for soils: part 8 determination of water content dry density relation using heavy compaction." BIS, New Delhi.

[22] ASTM D 1557 (2000). "Standard test methods for laboratory compaction characteristics of soil using modified effort." Philadelphia, U.S.A.
[23] IS: 2720 Part-7 (1987). "Methods of test for soils: part 7 determination of water content dry density relation using light compaction." BIS, New Delhi.

[24] ASTM D 698 (2000a). "Standard test methods for laboratory compaction characteristics of soil using standard effort." Philadelphia, U.S.A.

[25] Toth, P. S., Chan, H. T., and Cragg, C. B. (1988). "Coal ash as structural fill with special reference to Ontario experience." Canadian Geotechnical Journal, 25, 694-704.

[26] Martin, J. P., Collins, R. A., Browning, J. S., and Biehl, F. J. (1990). "Properties and use of fly ashes for embankments." Journal of Energy Engineering, 116 (2), 71-86.

[27] Santayana, F. P., and Mazo, C. O. (1994). "Behaviour of fly ash in experimental embankment." XII International Conference on Soil Mechanics and Foundation Engineering, New Delhi, 1603-1606. 